Fourth International Conference on Sustainable Construction Materials and Technologies http://www.claisse.info/Proceedings.htm

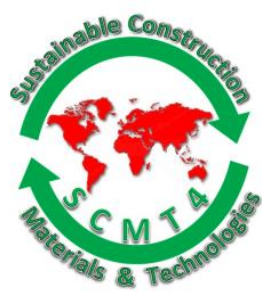

SCMT4

Las Vegas, USA, August 7-11, 2016

\title{
Effect of Moisture Content of Wet Fly Ash on Basic Properties of Mortar and Concrete
}

\author{
W. Saengsoy*1, T. Nguyen ${ }^{2 \mathrm{a}}$, R. Chatchawan ${ }^{2 \mathrm{~b}}$ and S. Tangtermsirikul ${ }^{2 \mathrm{c}}$ \\ ${ }^{1}$ Construction and Maintenance Technology Research Center (CONTEC), School of Civil Engineering \\ and Technology, Sirindhorn International Institute of Technology (SIIT), Thammasat University, \\ Pathumthani, 12120,THAILAND. Email: <warangkana@siit.tu.ac.th> \\ ${ }^{2}$ School of Civil Engineering and Technology, Sirindhorn International Institute of Technology (SIIT), \\ Thammasat University, Pathumthani, 12120, THAILAND. \\ ${ }^{2 a}$ Email:<emb.bichthuy@gmail.com>, ${ }^{2 b}$ Email:<rachot.ccw@hotmail.com>, \\ ${ }^{2 c}$ Email:<somnuk@siit.tu.ac.th>.
}

\begin{abstract}
This study is aimed to investigate feasibility of using wet low $\mathrm{CaO}$ fly ash as a cement replacing material in concrete. Effect of moisture content of wet fly ash on basic properties of mortar and concrete is studied. The properties of mortar and concrete made with the wet fly ash are investigated and compared with those made with dry fly ash. Wet fly ashes prepared in the laboratory are used in the investigation. Moisture contents of the wet fly ashes are $25 \%, 45 \%$, and $65 \%$. The wet exposure period of fly ash is 3 months. The test results revealed that strength activity index and flow of mortar made with wet fly ash are slightly improved. Slump and compressive strength of concrete made with wet fly ash are also improved when compared to those made with dry fly ash. The effect of different moisture contents of the wet fly ash can be explained by the concept of double mixing method. The micro hardness test results showed that ITZ of the concrete made with wet fly ash is improved due to the effect of double mixing method.
\end{abstract}

\section{INTRODUCTION}

Fly ash is one of the by-products derived from the coal combustion. In Thailand, almost 3 million tons of fly ash is produced annually. In the past, almost all produced fly ash had been used in concrete industry. However, it is estimated that about 0.6 to 0.7 million tons of fly ash, which is in excess of the demand, is being dumped without effective use during recent years. Some un-used fly ashes are water-sprayed to have moisture content about $15 \%$ to $20 \%$ before being dumped near the power plants. This produces large stocks of wet fly ash which are needed to be more properly managed. Use of wet fly ash as a cement replacing material in concrete seems to be possible in practice [Haldive and Kambekar 2013; Andrew 2011], especially for the low $\mathrm{CaO}$ fly ash. The high $\mathrm{CaO}$ fly ash, since partially cementitious, is difficult to be reused as a pozzolan if wetted. Additional drying and grinding processes are required for wet high $\mathrm{CaO}$ fly ash if it is to be reused [Cheeratot and Jaturapitakkul 2004], which makes it not cost effective in 
addition to the loss of reactivity when wet. Therefore, the possibility of using wet fly ash in concrete is studied for the low $\mathrm{CaO}$ fly ash. Since moisture content of the dumped wet fly ash can vary depending upon the exposing environment, effect of the moisture content of wet fly ash on properties of mortar and concrete is investigated. Wet fly ash used in this study is prepared in laboratory by varying moisture contents and with an exposure period of 3 months. Properties of wet fly ash and basic properties of mortar and concrete made with the wet fly ash are investigated and compared with those made with originally dry fly ash.

\section{EXPERIMENTAL PROGRAM}

Materials. Type I Ordinary Portland cement (OPC) complying with ASTM C150 was used. Two types of low $\mathrm{CaO}$ fly ash (FA-HM and FA-HS) produced from different blended-coal ratios and coal sources were used. FA-HM is fly ash produced from a blended Hunter Valley and Melawan sources. FA-HS is fly ash produced from a blended Hunter Valley and Spring Creek sources. Wet fly ashes were prepared in the laboratory by adding water into the dry fly ashes to achieve moisture contents of $25 \%, 45 \%$, and $65 \%$. Wet fly ashes with moisture contents of $25 \%, 45 \%$, and $65 \%$, prepared from FA-HM, are named as FAHM-25, FA-HM-45, and FA-HM-65, respectively, while those prepared from FA-HS are FA-HS-25, FAHS-45, and FA-HS-65, respectively. The wet fly ashes were kept in the prepared conditions for 3 months before being tested in order to simulate wet exposure period of the wet fly ash at the real site of which its wet exposure period is about 3 months. Natural river sand and crushed limestone were used as the fine aggregate and coarse aggregate in the tests, respectively. The specific gravity based on saturated-surface dry condition (SSD) of the sand and coarse aggregate were 2.60 and 2.72, respectively.

Mixture proportions. Mortars were prepared with sand to binder ratio of 2.75 by weight. The replacement percentage of fly ash in the mortars was $20 \%$ by weight. Water to binder ratio $(\mathrm{w} / \mathrm{b})$ was varied to obtain flow of $110 \pm 5$ for testing water requirement and strength activity index of mortar. While water to binder ratio $(\mathrm{w} / \mathrm{b})$ of 0.5 was used for flow test. Slump and compressive strength of concrete with water to binder ratios $(\mathrm{w} / \mathrm{b})$ of 0.45 and 0.55 were measured. The replacement ratios of fly ash for producing concrete were $0,0.3$ and 0.5 . Only one type of fly ash (FA-HM) was used for testing concrete.

Test methods. The basic properties of wet fly ash including chemical and physical properties were tested. Chemical compositions of OPC and fly ash were analyzed by X-ray fluorescent analysis (XRF), while other physical properties were tested according to their corresponded ASTM standards. Water requirement and strength activity index of mortar were tested according to ASTM C311. Flow of mortar was tested according to ASTM C1437. Slump and compressive strength of concrete were tested according to ASTM C143 and ASTM C39, respectively. The mortar and concrete specimens were prepared and cured in water for 3, 7, 28 and 91 days before being tested for strength activity index and compressive strength, respectively. Three specimens of the mortar and the concrete were prepared for each test age.

\section{RESULTS AND DISCUSSIONS}

Basic properties of fly ash. Specific gravity of OPC, dry fly ash and wet fly ashes is shown in Table 1. The specific gravity of the wet fly ash is similar to the originally dry fly ash. The specific gravity of the wet fly ash is unaffected by moisture contents. Blaine's fineness values and median particle sizes of FAHM and FA-HS are comparable as shown in Table 2. The particle size of the fly ash is slightly larger than that of the OPC. Chemical compositions of OPC, dry fly ash and wet fly ashes are given in Table 3. It can be seen that the chemical composition and loss on ignition (LOI) of the wet fly ash is unchanged when compared to that of the originally dry fly ash, indicating no reaction occurred during wet exposure period of the fly ash. The chemical composition of the wet fly ash with different moisture contents is also 
similar. All fly ash samples have low $\mathrm{CaO}$ content, which is mostly lower than $2 \%$ except FA-HM. The sum of three main oxides $\left(\mathrm{SiO}_{2}, \mathrm{Al}_{2} \mathrm{O}_{3}\right.$, and $\left.\mathrm{Fe}_{2} \mathrm{O}_{3}\right)$ is about $86 \%$. All fly ashes have quite high loss on ignition (LOI) but low $\mathrm{SO}_{3}$ content which conform to the requirements of ASTM C618 (Class F) and TIS 2135 (Class 2a).

Table 1. Specific Gravity of OPC, Dry Fly Ash, and Wet Fly Ash

\begin{tabular}{|c|c|c|c|c|c|c|c|c|c|}
\hline Sample & OPC & FA-HM & $\begin{array}{c}\text { FA- } \\
\text { HM-25 }\end{array}$ & $\begin{array}{c}\text { FA- } \\
\text { HM-45 }\end{array}$ & $\begin{array}{c}\text { FA- } \\
\text { HM-65 }\end{array}$ & FA-HS & $\begin{array}{c}\text { FA-HS- } \\
25\end{array}$ & $\begin{array}{c}\text { FA-HS- } \\
45\end{array}$ & $\begin{array}{c}\text { FA-HS- } \\
65\end{array}$ \\
\hline $\begin{array}{c}\text { Specific } \\
\text { gravity }\end{array}$ & 3.11 & 2.11 & 2.12 & 2.15 & 2.14 & 2.1 & 2.1 & 2.11 & 2.09 \\
\hline
\end{tabular}

Table 2. Blaine Fineness and Median Particle Size of OPC and Dry Fly Ashes

\begin{tabular}{|c|c|c|c|}
\hline Sample & OPC & FA-HM & FA-HS \\
\hline Blaine fineness $\left(\mathrm{cm}^{2} / \mathrm{g}\right)$ & 3,660 & 3,400 & 3,350 \\
\hline Median particle size $(\mu \mathrm{m})$ & 18.22 & 21.76 & 22.61 \\
\hline
\end{tabular}

Table 3. Chemical Compositions of OPC, Dry Fly Ash, and Wet Fly Ash

\begin{tabular}{|l|c|c|c|c|c|c|c|c|c|}
\hline & OPC & FA-HM & $\begin{array}{c}\text { FA- } \\
\text { HM-25 }\end{array}$ & $\begin{array}{c}\text { FA- } \\
\text { HM-45 }\end{array}$ & $\begin{array}{c}\text { FA- } \\
\text { HM-65 }\end{array}$ & FA-HS & $\begin{array}{c}\text { FA-HS- } \\
25\end{array}$ & $\begin{array}{c}\text { FA-HS- } \\
45\end{array}$ & $\begin{array}{c}\text { FA-HS- } \\
65\end{array}$ \\
\hline $\mathrm{SiO}_{2}$ & 19.7 & 61.09 & 61.39 & 61.26 & 61.3 & 63.53 & 63.26 & 63.84 & 62.89 \\
\hline $\mathrm{Al}_{2} \mathrm{O}_{3}$ & 5.19 & 20.35 & 19.99 & 20.11 & 20.06 & 20.81 & 21.14 & 20.26 & 20.75 \\
\hline $\mathrm{Fe}_{2} \mathrm{O}_{3}$ & 3.34 & 5.20 & 5.32 & 5.19 & 5.14 & 4.06 & 4.04 & 4.07 & 4.12 \\
\hline $\mathrm{CaO}$ & 64.8 & 2.32 & 1.75 & 1.83 & 1.90 & 1.84 & 1.85 & 1.92 & 1.92 \\
\hline $\mathrm{MgO}$ & 1.20 & 1.35 & 1.36 & 1.35 & 1.37 & 1.00 & 0.92 & 0.96 & 0.98 \\
\hline $\mathrm{SO}_{3}$ & 2.54 & 0.28 & 0.28 & 0.21 & 0.25 & 0.15 & 0.21 & 0.20 & 0.17 \\
\hline $\mathrm{Na}_{2} \mathrm{O}$ & 0.16 & 0.79 & 1.16 & 1.33 & 1.03 & 0.95 & 0.87 & 1.13 & 1.15 \\
\hline $\mathrm{K}_{2} \mathrm{O}$ & 0.44 & 1.36 & 1.32 & 1.4 & 1.41 & 1.23 & 1.20 & 1.22 & 1.29 \\
\hline $\mathrm{TiO}_{2}$ & 0.25 & 0.98 & 1.01 & 0.93 & 0.99 & 1.05 & 1.03 & 1.02 & 1.05 \\
\hline $\mathrm{P}_{2} \mathrm{O}_{5}$ & 0.11 & 0.23 & 0.30 & 0.32 & 0.30 & 0.29 & 0.40 & 0.31 & 0.35 \\
\hline $\mathrm{SrO}^{\mathrm{ZrO}}$ & - & 0.09 & 0.08 & 0.08 & 0.08 & 0.12 & 0.12 & 0.11 & 0.12 \\
\hline $\begin{array}{l}\mathrm{Free} \\
\mathrm{CaO}\end{array}$ & - & 0.07 & 0.07 & 0.06 & 0.07 & 0.08 & 0.07 & 0.07 & 0.08 \\
\hline $\mathrm{LOI}$ & 2.10 & 5.68 & 5.81 & 5.82 & 5.94 & 4.55 & 4.81 & 4.84 & 4.99 \\
\hline
\end{tabular}

Water requirement and flow of mortars. Water requirement of mortars is shown in figure 1. All mixtures except FA-HM have lower water requirement than OPC. The water requirement of wet fly ash relative to that of the dry fly ash is shown in figure 2. It is obviously seen that mortars with dry fly ash have higher water requirement than mortars with wet fly ash. Water requirements of mortars with different moisture contents of the wet fly ash are similar. It is noted that the amount of moisture in the wet fly ash was compensated already in the mix design and preparation. 
Flow of mortar with controlled water to binder ratio $(\mathrm{w} / \mathrm{b}=0.5)$ is presented in figure 3 . It can be seen that flow of mortar with fly ash (except FA-HM) is larger than that of the OPC mortar. The flow of wet fly ash relative to that of dry fly ash is shown in Figure 4. It is clearly seen that the flow of mortars with wet fly ash is larger than that of dry fly ash.

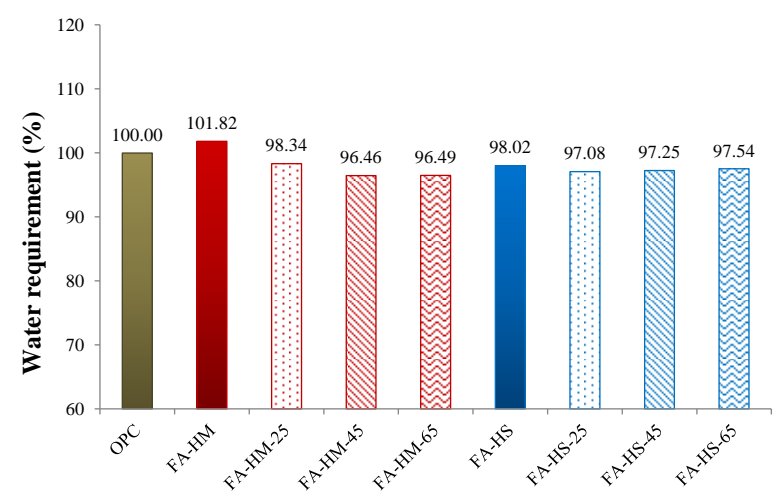

Figure 1. Water requirement of mortars

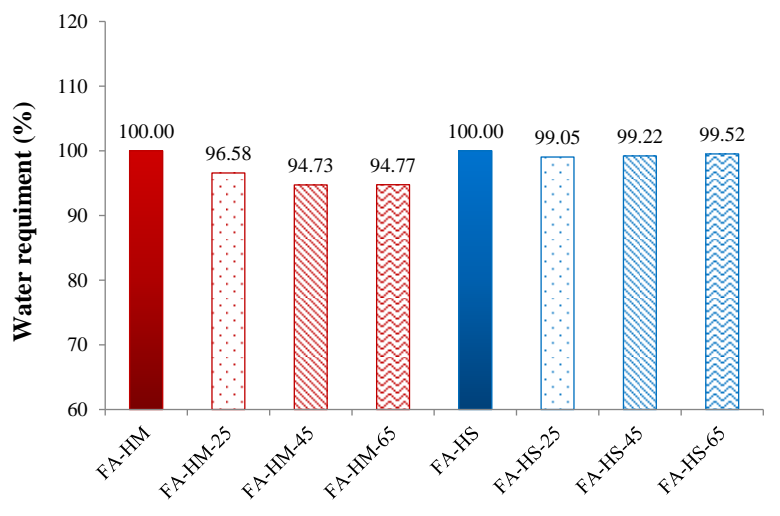

Figure 2. Water requirement of mortars made with wet fly ash relative to that of dry fly ash

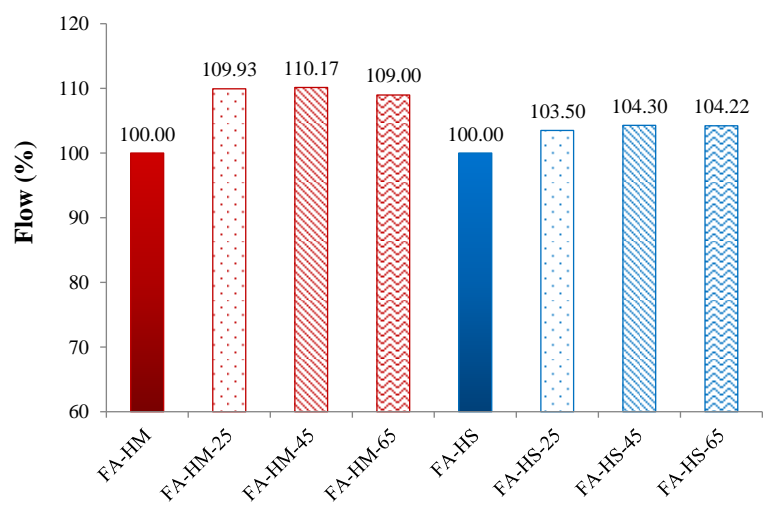

Figure 4. Flow of mortars made with wet fly ash relative to that of dry fly ash
Figure 3. Flow of mortars with controlled water to binder ratio

\section{Strength activity index of mortars}

Strength activity indices of mortars made with FA-HM and FA-HS are shown in Figure 5. The strength activity indices at 3,7, and 28 days of fly ash mortar are lower than that of the OPC mortar. However, the strength activity indices at 28 days are higher than $75 \%$. At 91 days, the strength activity indices of fly ash mortars are higher than that of the OPC mortar due to the pozzolanic reaction of the fly ash. It is clearly seen that the strength activity indices of mortars with wet fly ash are higher than that of the mortars with dry fly ash. This is because their water to binder ratios (water requirements) are lower than that of the dry fly ash.

When water to binder ratio of the mixture is controlled, the strength activity indices of mortars with wet fly ash are also slightly higher than that of the mortars with dry fly ash. The improved strength activity index when using wet fly ash is remarkably seen at early age. Figure 6 shows strength activity indices of mortars with controlled water to binder ratio. 


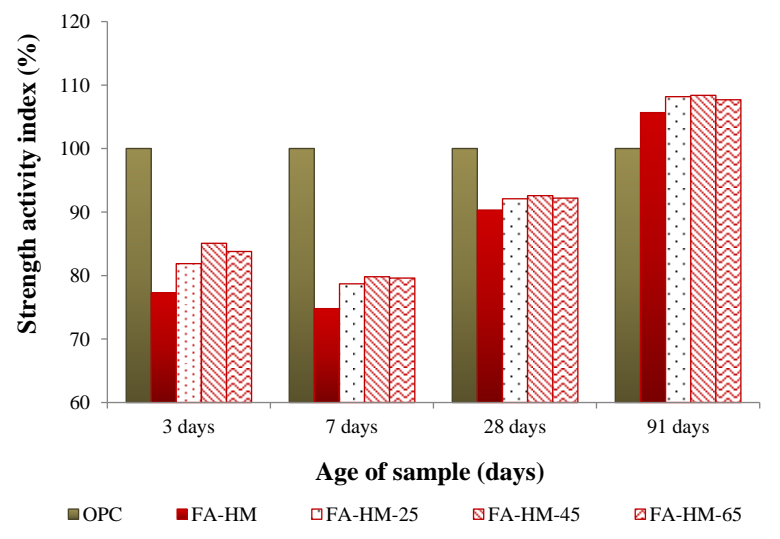

(a) FA-HM

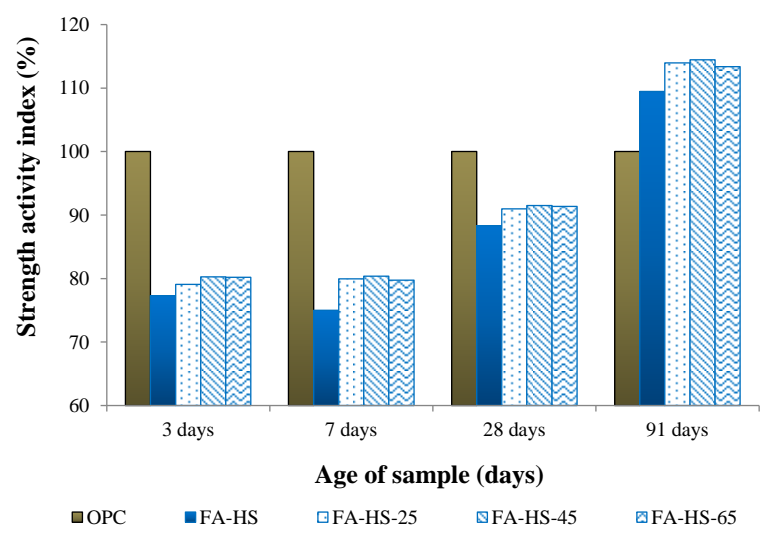

(b) FA-HS

Figure 5. Strength activity indices of mortars

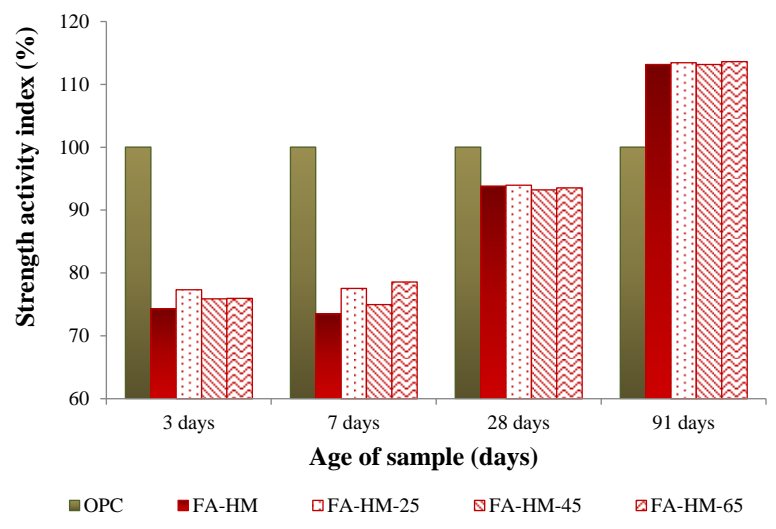

(a) FA-HM

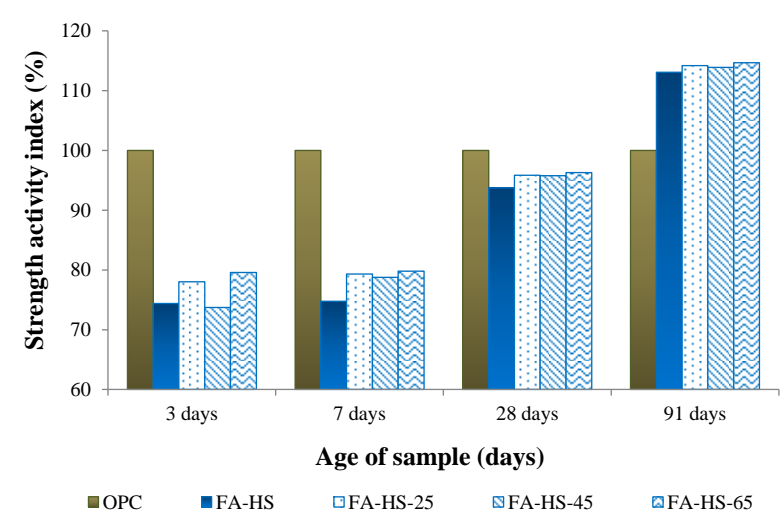

(b) FA-HS

Figure 6. Strength activity indices of mortars with controlled water to binder ratio

\section{Slump of concrete}

Slump of fresh concrete made with and without fly ashes is shown in figure 7. It is noted that only one type of fly ash (FA-HM) was used for testing slump of concrete. It can be seen that the slump of concrete containing dry fly ash is lower than that of the OPC concrete. This may due to an irregular shape of some particles and a quite high LOI content of the fly ash (FA-HM). In case of low water to binder ratio $(\mathrm{w} / \mathrm{b}=$ 0.45), the slump of concretes with and without wet fly ash is almost similar for both $30 \%$ and $50 \%$ replacements of fly ash. The effect of moisture content of wet fly ash on the slump of concrete is noticeable in the case of high water to binder ratio $(\mathrm{w} / \mathrm{b}=0.55)$, demonstrating that wet fly ash can improve the slump of concrete when compared with dry fly ash. The wet fly ash with $65 \%$ of moisture content (FA-HM-65) is more effective than others. It can increase slump of the concrete by $20 \mathrm{~mm}$ and 15 $\mathrm{mm}$ for $30 \%$ and $50 \%$ replacements of fly ash, respectively. 


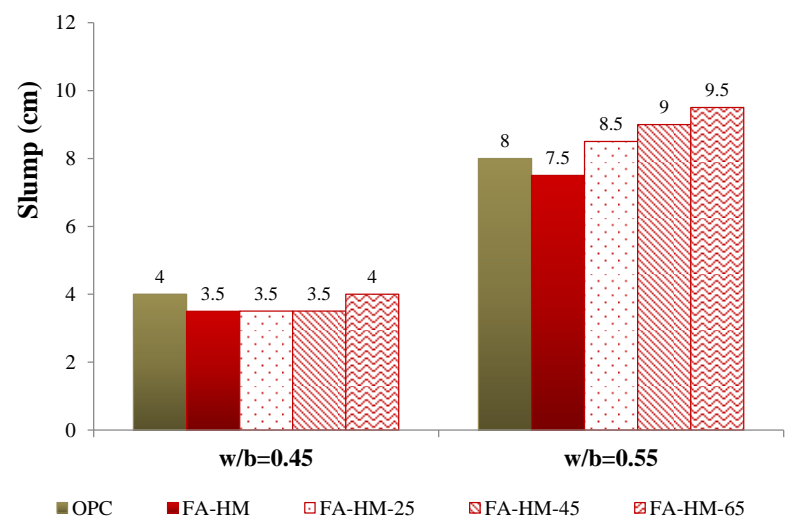

(a) $30 \%$ replacement of fly ash

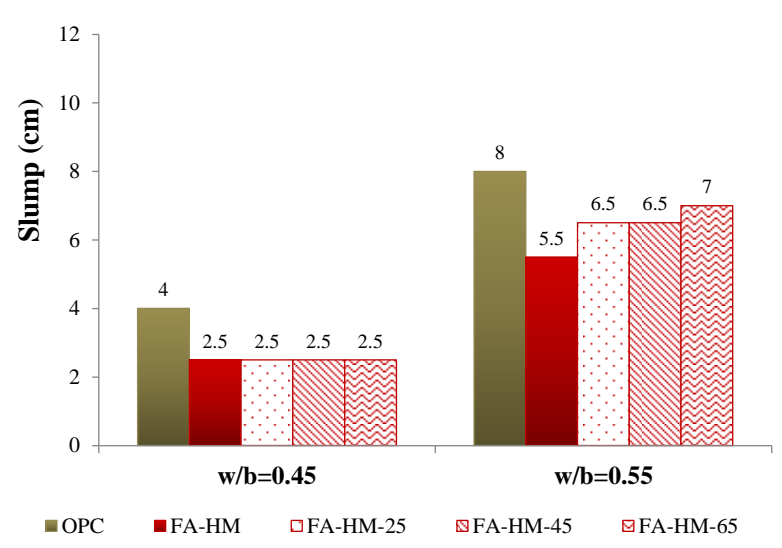

(b) $50 \%$ replacement of fly ash

Figure 7. Slump of Concrete

\section{Compressive strength of concrete}

Figure 8 and figure 9 illustrate compressive strength of concrete with $w / b=0.45$ and $w / b=0.55$, respectively. Compressive strength of concrete with fly ashes is lower than that of concrete with cement only. Although the concretes with fly ash have lower compressive strength at early age, their compressive strength in long term (91 days) is almost equal to that of the OPC concrete, especially for the concrete with $\mathrm{w} / \mathrm{b}=0.55$ and $30 \%$ replacement of fly ash, due to pozzolanic reaction of the fly ash at later age. Compressive strength of concrete made with wet fly ash is slightly improved when compared with that of the dry fly ash concrete (except FA-HM with w/b $=0.55$ and $30 \%$ replacement of fly ash at 3 days). When compared with the test results of strength activity index of mortars, it seems that the improvement of strength of wet fly ash in mortar is more effective than in concrete.

Compressive strength and slump of concrete as well as strength activity index and flow of mortars made with wet fly ash are improved when compared with dry fly ash, possibly due to the effect of preexistence of water in the fly ash causing the effect of double mixing. The effect of double mixing will be explained in the following section.

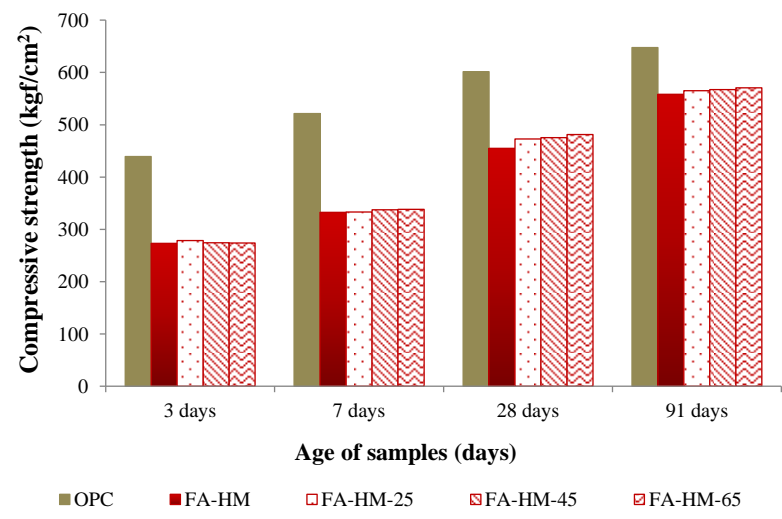

(a) $30 \%$ replacement of fly ash

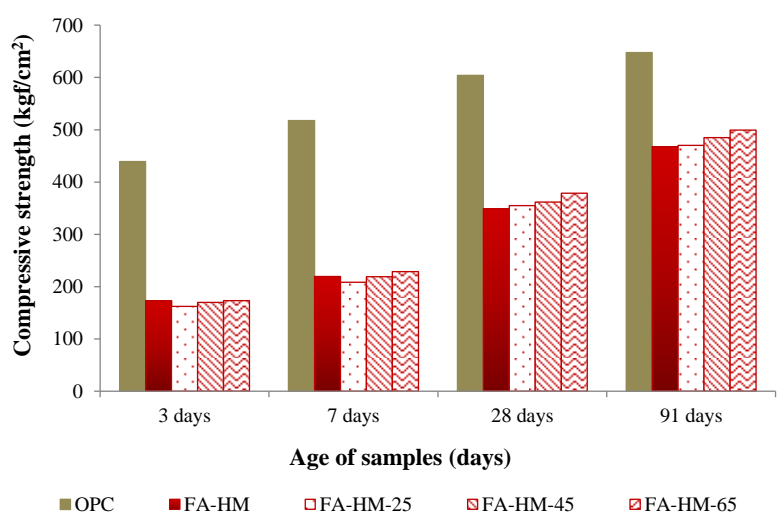

(b) $50 \%$ replacement of fly ash

Figure 8. Compressive Strength of Concrete with $w / b=0.45$ 


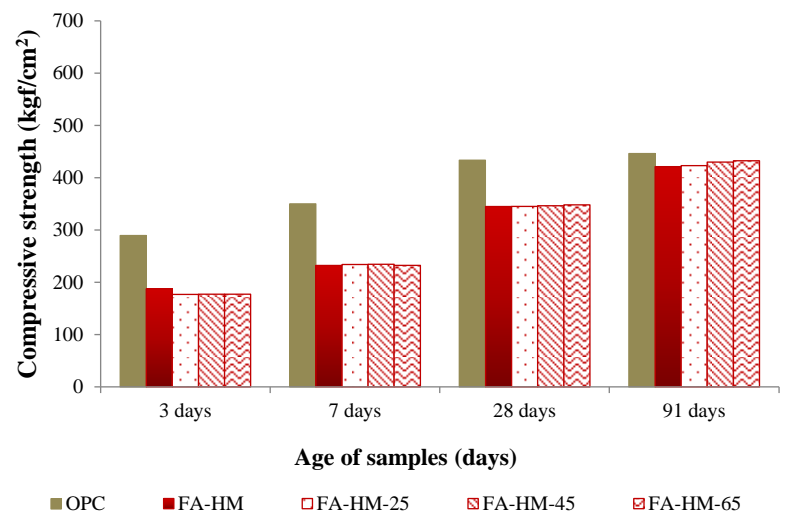

(a) $30 \%$ replacement of fly ash

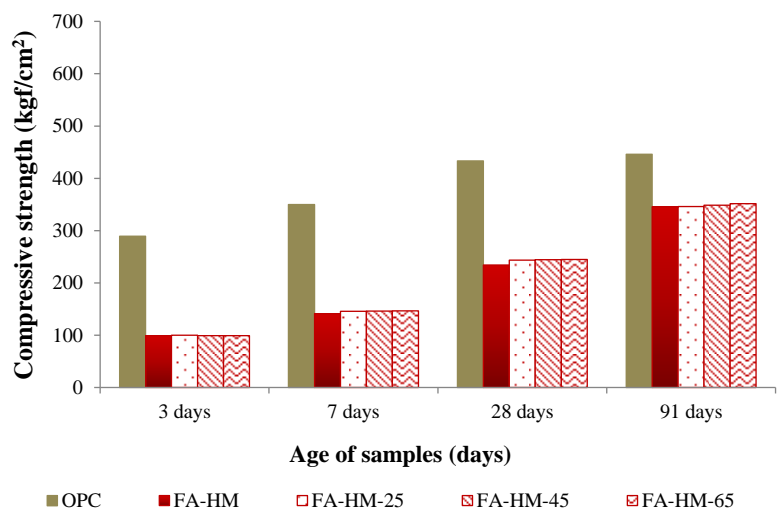

(b) $50 \%$ replacement of fly ash

Figure 9. Compressive Strength of Concrete with w/b $=0.55$

\section{DOUBLE MIXING METHOD}

Mixing water is generally added only one time during mixing of mortar or concrete, which is generally known as a single mixing method. In the double mixing method, the charging of water is divided into two stages [Otsuki et al. 2003]. It was found in the literature that the improvement in strength of recycled aggregate concrete can be achieved by using the double mixing method. The amount of the first charge of water also has an effect on the properties of concrete [Otsuki et al. 2003]. When wet fly ash is used in the mixture, preexistence of water in the wet fly ash can be considered as the first charge of water in the double mixing method. Therefore, moisture content of the wet fly ash is supposed to have effects on the properties of mortar and concrete as well. It was confirmed in the author's previous study that flow of mortar made with wet fly ash is improved due to preexistence of water in the wet fly ash causing the effect of double mixing [Saengsoy et al. 2014]. In this study, effect of double mixing method on micro hardness of concrete is elucidated as follows:

Effect of double mixing method on micro hardness of concrete. The double mixing method is known to improve the quality of interfacial transition zone (ITZ) of normal aggregate concrete [Otsuki et al. 2003]. In this study, Vickers micro hardness test on the ITZ of concrete made with dry and wet fly ash was conducted. Concrete samples with water to binder ratio of 0.55 and $30 \%$ replacement of fly ash were used. The Vickers micro hardness was measured within the distance of 20-250 $\mu \mathrm{m}$ from the aggregate surface. The average values of Vickers micro hardness measured at $50 \pm 30 \mu \mathrm{m}$ distance from the surface of sand particles in mixtures made with dry and wet fly ashes are shown in Table 4. The profiles of hardness values at different distance from sand particles are shown in figure 10. The hardness values near sand particle of concretes made with wet fly ash are higher than that of the concrete made with dry fly ash. The hardness values increase with an increase in moisture content of the wet fly ash. The hardness values of the paste near sand particles of concrete made with dry fly ash are lower when compared to the values measured far from the sand particles, which is a typical behavior for normal aggregate due to the effect of interfacial transition zone (ITZ). On the other hand, the hardness values of concrete made with wet fly ash decrease as the distance from the sand particles increases. However, the hardness values measured far from the sand particles of concrete made with the wet fly ash are only slightly lower than that of the dry fly ash concrete. The same tendency was also found in the Vickers micro hardness test near coarse aggregate particles though the differences of hardness values between wet fly ash concrete and dry fly ash concrete are smaller when compared to the case of measurement near the sand particles, as shown in figure 11. This is the reason why the effect of wet fly ash on strength activity index of mortars is more obvious than the case of compressive strength of concrete. It is confirmed that ITZ of the concrete made 
with wet fly ash is improved due to the effect of double mixing method. The improved ITZ increases compressive strength of the concrete made with wet fly ash.

Table 4. Average Values of Vickers Micro Hardness near Sand Particles of Concrete made with Dry and Wet Fly Ashes

\begin{tabular}{|c|c|c|c|c|}
\hline Samples & FA-HM & FA-HM-25 & FA-HM-45 & FA-HM-65 \\
\hline Vickers micro hardness & 43.58 & 48.41 & 56.13 & 63.43 \\
\hline
\end{tabular}

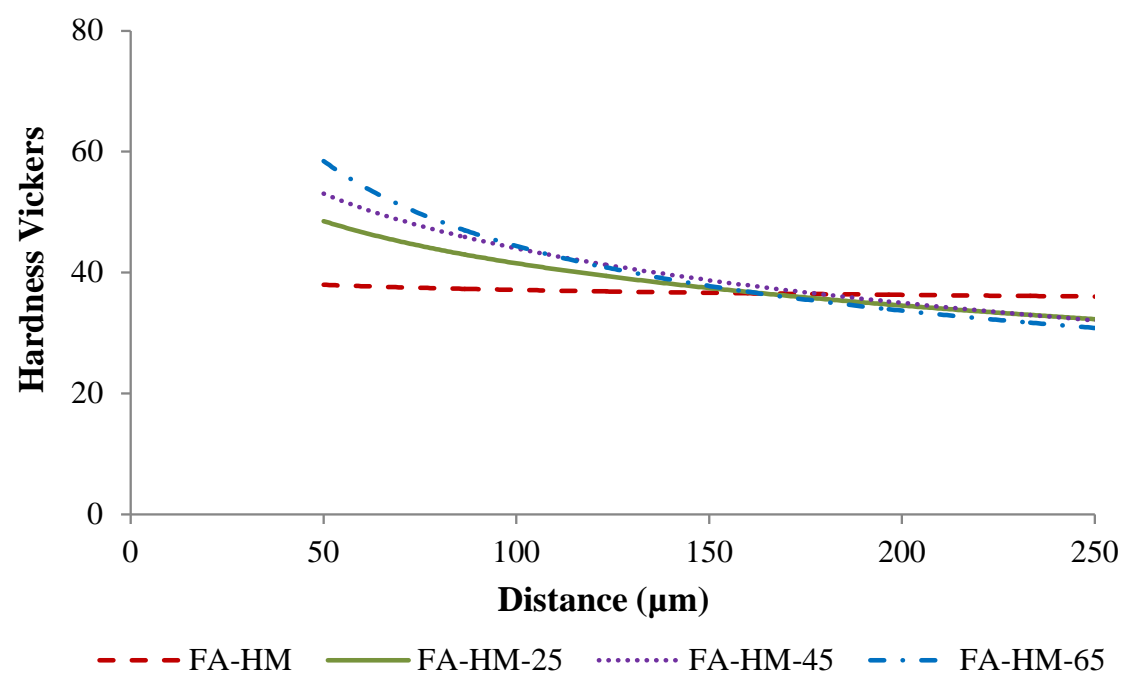

Figure 10. Profile of Hardness Values from Polynomial Fit at Different Distance from Sand Particles of Concrete made with Dry and Wet Fly Ashes

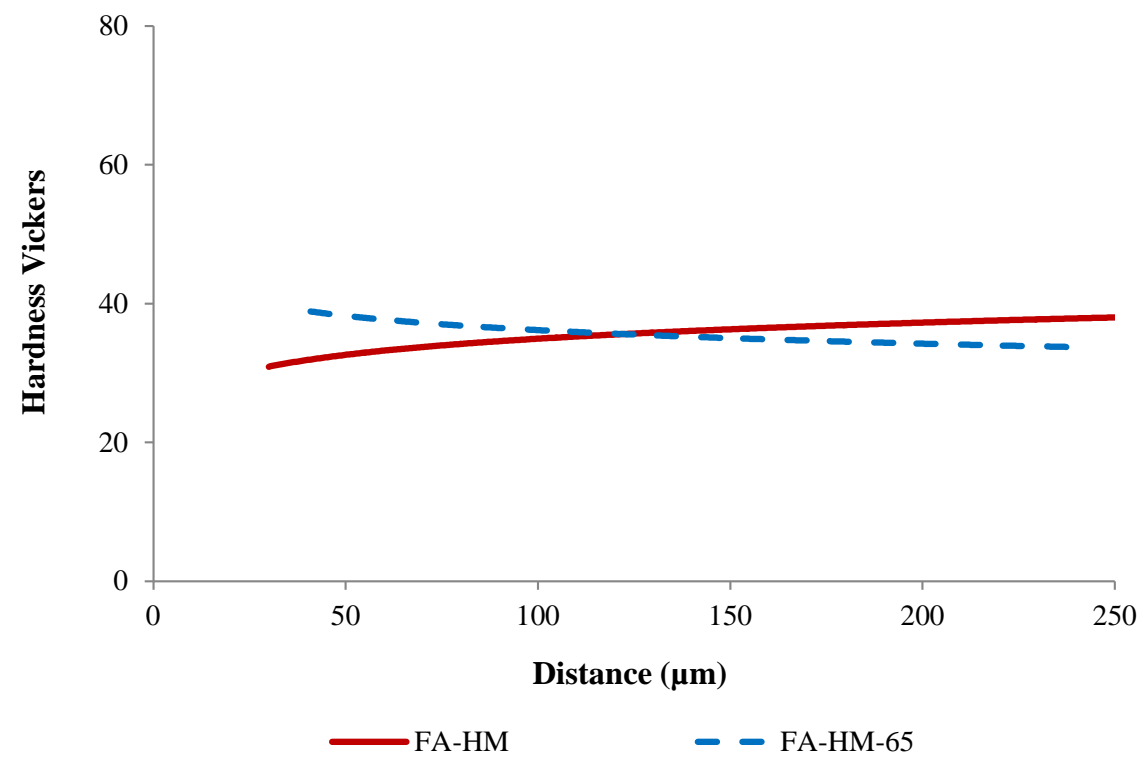

Figure 11. Profile of Hardness Values from Polynomial Fit at Different Distance from Coarse Aggregate Particles of Concrete made with Dry and Wet Fly Ash 


\section{CONCLUSION}

Effect of moisture content of wet fly ash on basic properties of mortar and concrete were investigated. From the experimental investigations, performances of wet fly ash when compared with dry fly ash could be identified and summarized in Table 5. It can be concluded that chemical composition and specific gravity of wet fly ash is unchanged when compared to that of the originally dry fly ash. Flow and strength activity index of mortars with wet fly ash are higher than that of the mortars with dry fly ash. Slump and compressive strength of concrete made with wet fly ash are also slightly improved. Preexistence of water in the wet fly ash (moisture content) is considered as the first charge of water in the double mixing method which leads to improvement of the ITZ of concrete made with the wet fly ash. The improved ITZ increases compressive strength of the concrete made with wet fly ash. Overall, the test results revealed that it is feasible to use wet low $\mathrm{CaO}$ fly ash in concrete production without showing worse performance when compared with dry fly ash.

Table 5. Summary of Performances of Wet Fly Ash when compared with Dry Fly Ash

\begin{tabular}{|l|c|c|c|}
\hline \multicolumn{1}{|c|}{ Properties } & \multicolumn{3}{c|}{ Performances } \\
\cline { 2 - 4 } & worse & same & better \\
\hline Chemical composition & & $\bullet$ & \\
Specific gravity & & $\bullet$ & $\bullet$ \\
Water requirement & & & $\bullet$ \\
Flow of mortar & & & $\bullet$ \\
Strength activity index of mortar & & $\bullet$ \\
Slump of concrete & & $\bullet$ & \\
Compressive strength of concrete & & & \\
\hline
\end{tabular}

\section{ACKNOWLEDGEMENTS}

The authors would like to acknowledge the research support from BLCP Power Co., Ltd. and the Center of Excellence in Material Science, Construction and Maintenance Technology, Thammasat University.

\section{REFERENCES}

Andrew B. Aceves P.G. (2011). "The use of Non-Commercial Fly ash in Roller compacted concrete structures", World of Coal Ash (WOCA) conference, Denver, CO, USA May 9-12, 2011.

ASTM C143, Standard Test Method for Slump of Hydraulic-Cement Concrete. ASTM International, West Conshohocken, PA, 4 pages.

ASTM C1437, Standard Test Method for Flow of Hydraulic Cement Mortar. ASTM International, West Conshohocken, PA, 2 pages.

ASTM C150. "Standard Specification for Portland Cement," ASTM International, West Conshohocken, PA, 8 pages.

ASTM C311, Standard Test Methods for Sampling and Testing Fly Ash or Natural Pozzolans for Use as a Mineral Admixture in Portland-Cement Concrete. ASTM International, West Conshohocken, PA, 10 pages.

ASTM C39, Standard Test Method for Compressive Strength of Cylindrical Concrete Specimens. ASTM International, West Conshohocken, PA, 7 pages. 
ASTM C618. "Standard Specification for Coal Fly Ash and Raw or Calcined Natural Pozzolan for Use in Concrete." ASTM International, West Conshohocken, PA, 3 pages.

Cheeratot, R. and Jaturapitakkul, C. (2004). "A Study of Disposed Fly Ash from Landfill to Replace Portland Cement", Waste Management, Volume 24, Issue 7, 2004, 701-709.

Haldive, S.A. and Kambekar, A. R. (2013). "Experimental Study on Combined Effect of Fly Ash and Pond Ash on Strength and Durability of Concrete", International Journal of Scientific \& Engineering Research. Volume 4, Issue 5, May-2013.

Otsuki, N., Miyazato, S. and Yodsudjai, W. (2003). "Influence of Recycled Aggregate on Interfacial transition Zone, Strength, Chloride Penetration and Carbonation of Concrete", Journal of materials in civil engineering, Vol. 15, No. 5, 2003, 443-451.

Saengsoy, W., Nguyen T. B. T, and Tangtermsirikul, S. (2014). "A Study on Basic Properties of Mortar made with Wet Fly Ash" In Proceedings of the 6th International Conference of Asian Concrete Federation (ACF 2014) [CD-ROM], 21-24 September 2014, Seoul, Korea, 949-955.

TIS 2135. "Coal Fly Ash for Use as an Admixture in Concrete". Thai Industrial Standards Institute, 10 pages. 